\title{
ENYEDI ÉVA
}

\section{A SZÜRKE GALAMB EVANGÉLIUMA INTERTEXTUALITÁS ÉS PARAFRÁZIS'}

"Jézus Krisztus ma, Magyarországon, női testben"

\section{Szinopszis - A mi történetünk}

Karácsony napján a vidéki kisváros polgármesteréhez, Hajdú Lászlóhoz két furcsa üzletasszony érkezik a Távol-Keletről. Előnyös üzleti ajánlat helyett egy gyermekről érdeklődnek, aki ezen a napon, ebben a városban fog megszületni. A csalódott polgármester értetlenül fogadja őket, sőt mérgében megátkozza a gyermeket, amit a jelen lévő Angyal Hajnal - Hajdú titkárnője és szeretője "halálosan" komolyan vesz, és elhatározza, hogy megöli az összes aznap világra jött csecsemőt. A két japán nő egy csillagot követve továbbindul a gyermek keresésére.

Eközben a határon túli Máté József és vajúdó unokahúga, az együgyű Marika szállást keresnek a városban. A szülés megindul a Hotel Kikelet recepcióján, a portás végzi el a császármetszést a béranyaként teherbeejtett Marikán. A védőnőként bemutatkozó Hajni azt hazudja, hogy védőoltást akar beadni az újszülöttnek, de mielőtt sikerülne megmérgeznie ezt a kisbabát is, megérkezik a harmadik japán üzletasszony, és elüzi Hajnit. A szerencsésen megmenekült gyermek, Máté Edina már hatéves korában kívülről tudja a Bibliát, húszévesen pedig váratlanul kinyilvánítja különös elképzelését isteni származásával kapcsolatban. Nevelőapja esküvőjén elárulja, hogy ő volt az, aki miatt azon a bizonyos karácsonyon valaki meggyilkolt tizenhárom újszülöttet, borrá változtatja a vizet, majd megkereszteli későbbi tanítványait: nevelőanyját, Máté Marikát, a vőlegénytől viszolygó menyasszonyt, Bíró Melindát és a lelkifurdalástól évek óta gyötrődő Hajdú Lászlót, aki ezután Szürke Galamb néven ír könyvet Edina cselekedeteiről. Azt hirdeti továbbá, hogy a világon hatalmi „pólus-váltás" következik be, és a férfiak uralmát a nők veszik át. Különös nézetei miatt kirúgják a teológiáról, és gyermekkori pártfogója, Béla atya elhatározza, hogy elmegyógyintézetben fogja kigyógyíttatni őrültségéből.

Amikor azonban az orvos elé kerül, a történet bulgakovi fordulatot vesz. Edina a halálos beteg, istentagadó orvost a hit erejére emlékezteti, és felvillantja a gyógyulás lehetőségét. Megtörténik a második csoda: megcsörren a

1 Pintér Béla és Társulata: „Az Őrült, az Orvos, a Tanítványok és az Ördög” című előadásának (2007) próbafolyamata a dramaturg szemszögéből. A Szürke Galamb Evangéliuma egyébként szerepelt a munkacímek között, és utólag többször felmerült, hogy jobb lett volna, mint a "hosszú cím". 
doktor telefonja, és kiderül, hogy a torkában talált daganat pozitív szövettani eredménye téves volt, a doktor egészséges. A megrendült, megkönnyebbült orvos épelméjünek akarja nyilvánítani Edinát, aki azt állítja, hogy tanítványai egyszerűen félreértették, félremagyarázták szavait. Amikor Edina épp azt jövendöli, hogy az orvos nemsokára közveszélyes őrültnek fogja nyilvánítani, és elviteti egy elmegyógyintézetbe, ahol a betegek megerőszakolják, és felakasztják őt, megérkezik Béla atya egy vatikáni levéllel, a Szentszék üzenetével. Meghallgatták az "Ábrahámhegyi beszéd" tévéfelvételét, mindenben egyetértenek vele, megengedik a nők pappá szentelését, és örömmel visszafogadják Edinát az egyház kebelébe.

A volt titkárnő, Angyal Hajnal is megérkezik, aki annak érdekében, hogy visszacsábítsa Hajdút, ráveszi Melindát, - akit leszbikus hajlamai miatt Edina elzavart magától - hogy vádolja be egykori mesterét, miszerint tanítványait öngyilkosságra szólította fel, és szertartásain állatok szívének elfogyasztására kényszerítette őket. Tanúnak ő maga jelentkezik.

Edina nem tiltakozik, mert a vádakat, úgymint a Vatikán ajánlatát csupán ördögi kísértésnek tekinti. Hajdú is ellenáll a csábításnak.

Hajni addig erőszakoskodik, amíg az orvos, Bulgakov Pilátusához hasonlóan gyáva döntésre kényszerül: egy rosszhírű vidéki elmegyógyintézetbe utalja a lányt. Hajni Hajdút is megfenyegeti egy beutalóval, mire o "háromszor" is megtagadja Edinát.

A vallási megszállottságban tévelygő őrültek között bontakozik ki a történet végkifejlete, a kálvária. Az intézet lakói eksztatikus állapotban megerőszakolják, és felakasztják a messiásként tisztelt Edinát.

Az ügyből médiabotrány lesz, annál is inkább, mert Edina holtteste eltűnik. A rendőrség feltételezése szerint a holttestet a tanítványok lopták el, az országban azonban szárnyra kap egy szóbeszéd Edina feltámadásáról. A televízióban Hajni és Melinda tudósít a történtekről; meghívott vendég: az Edinát beutaló orvos, aki sajnálattal veszi tudomásul a történteket, és „mossa kezeit”. Az áruló Melinda a beszélgetés után öngyilkos lesz. A történet a húsvéti körmenettel zárul.

\section{A témaválasztás, az inspiráció}

Jézus története az emberiség kultúrájának egyik legalapvetőbb, legfontosabb toposza. Olyan forrás- és tudásanyag, mely alkotók és befogadók számára egyaránt kikerülhetetlen és kimeríthetetlen. Euripidész Bakhánsnők-jétől kezdve a középkori misztériumjátékokon és passiókon át a mai napig számos színpadi adaptációjával találkozhatunk.

Pintér Béla drámáiban több ízben is megjelenik a keresztény hithez és valláshoz való viszony², valamint korának világi ünnepei, a népi hagyományból

2 A katolikus mise szövegéből szó szerint idéz több darabjában is, lásd: A Sehova Kapuja (2000), A Sütemények Királynője (2003), Szutyok (2010). 
fakadó - valamilyen formában ma is továbbélő - modern rítusok, szokások, szertartások, mint például esküvő, temetés, születésnap stb.

Hogy a Megváltó életének feldolgozására miért épp 2007-ben került sor, arra több magyarázatot is találhatunk. Szenzációhajhász, leleplező alkotások évente jelennek meg Jézus életével kapcsolatban; a világ elnőiesedésének lehetőségét pedig a bulvársajtó, a féltudományos műsorok gyakran tárgyalják; azt mondhatjuk tehát, mindkét téma „benne van a levegőben”. De az inspiráló szikra kipattanásához akár egy másik műalkotás megtekintése is elég lehet. Ez esetben egy tizenhatodik századi festményé, mely kortárs környezetben ábrázolja Jézus életének egy epizódját: id. Bruegel Népszámlálás Betlehemben (The Census at Bethlehem) címü képének középpontjában észrevehető ugyan egy apró, szamárháton ülő Mária figura, de nagyobb hangsúlyt kapnak az őt körülvevő, egyszerű parasztemberek, a művész korának tipikus figurái és a jellegzetes németalföldi havas táj. ${ }^{3}$

Többek között ez a kép ihlette az előadás alapgondolatát. Vajon hogyan festene a Jézus-történet a mai Magyarországon? Mi lenne, ha a gyermek nem egy betlehemi istállóban, hanem egy magyarországi kisvárosi hotel garázsában születne? Ha a napkeleti bölcsek repülőgéppel érkeznének Japánból, és nem Heródesnél, hanem a kisváros polgármesterénél érdeklődnének a gyermek után? Ha a felcseperedő gyermek nem a zsidó, hanem a katolikus vallásban mutatna megdöbbentő jártasságot, később pedig keményen bírálná azt, amiért nem bíróság elé állítanák, hanem őrültek házába vinnék, ahol az ápolók figyelmét kijátszó őrültek megölnék őt? És végül, hogy kellőképp átérezhessük azt, mekkora megbotránkozást okozott a korabeli zsidó vallási vezetőknek Jézus azon kijelentése, hogy ő Isten fia, képzeljük el, hogy hősünk nő, Isten lányának tartja magát, az Anyaisten egyszülött lányának, akitől ő „közvetlenül” származik.

Bruegel festménye mellett a bibliai történet számos irodalmi interpretációja közül Bulgakov regénye, $A$ Mester és Margarita jelentette a legfontosabb hivatkozási pontot (Pintér Béla a regényt a Bibliához hasonlóan evidens, a nézőkkel "közös" tudásanyagnak tekintette).

Azokban, akik olvasták a regényt, Bulgakov Pilátus figurája lényegesen átszínezi az evangéliumokból ismert alakot. Pintér darabjának egyik kulcsfigurája, a lánymessiás épelméjűségéről döntő elmeorvos, a regényben szereplő Pilátus parafrázisa. ${ }^{4}$ Valamint a darab egyik kulcsgondolata: a hiteles elbeszélés lehe-

3 Brüsszel: Királyi Szépművészeti Múzeum, 1566.

4 Máté Edina nálunk nem az orvos fejfájását gyógyítja meg, mint Jesua Pilátusét, hanem egy téves diagnózisról világosítja fel egy perccel a másik orvos telefonhívása előtt. Az ezt követő párbeszédben dőlt betűvel jelölt mondatok szó szerinti idézetek:

„Orvos Honnan tudtad, hogy fel fog hívni az orvos?

Edina Nem tudtam. Én csak annyit mondtam, hogy talán felhív majd.

Orvos Jó. Ha mindenáron titkolni akarod, akkor titkold! Bár jobban tennéd, ha őszinte lennél hozzám, mert a sorsod egy hajszálon függ!

Edina Talán bizony azt hiszed, hogy te függesztetted fel, doktor úr?

Orvos Nem, de én elvághatom azt a hajszálat. 
tőségének megkérdőjelezése is megjelenik a regényben: a Jesuát bosszantó tanítvány, mesterének cselekedeteit sajátosan (hamisan?) interpretáló Lévi Máté bárki számára elrettentő példa, aki megpróbálná elmesélni Jézus történetét... ${ }^{5}$

\section{A feldolgozás}

Pintér Béla 2007 októberéig összesen tíz darabot írt, tíz előadást hozott létre, melyek mindegyike ősbemutató, teljesen eredeti, önálló történettel. Volt már példa irodalmi mú és konkrét történelmi esemény dokumentációjának felhasználására, ${ }^{6}$ de ezek mindig csak egy részét képezték a drámának, kontrasztul, apropóul szolgáltak egy mai, a szerzőt közvetlenül, személyesen érintő probléma megvilágításához.

Ha meg is jelent tehát az előadásokban valamilyen közismert motívum, a nézővel közös tudásanyag, a történet alakulása, a végkifejlet mindenképp meglepő, váratlan fordulatokon keresztül következett be. Az ismeretlenség, az újdonság feszültsége az utolsó pillanatig kitartott.

Ez esetben, a tizenegyedik darabnál a megvalósítás izgalmát nem a történet originalitása, hanem az adaptáció - a mai környezet, a drámai interpretáció problémájának megoldásai adták. Az eddigiekhez képest ez mindenképp újszerű kihívást jelentett, hiszen a történet menete, vége ismert minden néző számára, ezért sokkal inkább a hogyanra, a mikéntre, a történetmesélés módjára irányul a figyelem.

A Pintér darabjaiban oly gyakori „utolsó csavar”, mely váratlanságával elsöprő erővel hat, vagy ahhoz segít hozzá, hogy végképp összeálljon a kép ezúttal nem alkalmazható, hiszen minden meg van írva, a néző tudja, mire számítson, nincs szenzáció, nagy leleplezés. Felmerül a kérdés, mi is lehet vonzó abban, hogy elmondjunk, elismételjünk vagy meghallgassunk egy olyan történetet, amelyet már mindenki ismer valamilyen formában.

Edina Ebben tévedsz. Mert azt ugyebár elismered, hogy csak az vághatja el a hajszálat, aki felfüggesztette. Csend.

Orvos Te olvastál Bulgakovot, ugye?

Edina Nem. Soha életemben."

A párbeszédet lezáró kérdés pedig az intertextualitásra hívja fel a figyelmet ironikusan. „A legnagyobb bűn a gyávaság.” Jesua szó szerint idézett utolsó mondata többször is elhangzik a darabban.

5 Így beszél Bulgakovnál Jesua Lévi Mátéról: „Azok a jóemberek [...] nem tanultak semmit és mindent összezavartak, amit mondtam. Attól tartok, ez a zűrzavar még hosszú ideig el fog tartani. És mindennek az az oka, hogy ez az ember nem jegyzi fel híven a szavaimat. [...] Állandóan a nyomomban van azzal a kecskebőr pergamennel, és szüntelenül ír, jegyez. De én egyszer belenéztem a följegyzéseibe, és megrémültem. Egy árva szót sem mondtam mindabból, ami ott fel van írva." (Mihail BuLGAKov, A Mester és Margarita, ford. Szőlıősy Klára (Budapest: Európa Könyvkiadó, 1978), 22.

6 Kórház-Bakony (1999)és Hamvas Béla: Karnevál;Árva Csillag (2007)és Ivan Alexandrovics Goncsarov: Oblomov; Gyévuska (2003) és Dr. Somorjai Lajos: Megjártam a Don-kanyart. 
A nézők - akik a mi esetünkben többnyire nem tudják, mit fognak látni, ezért fokozatosan, az egyéni felkészültségtől, tudástól függően ismernek rá a témára, míg végül (szerencsés esetben) néző-közösséggé formálódva együtt követik, értékelik a megvalósítást, a megfelelés leleményességét, az eltérések frissítő, figyelemfelkeltő erejét ${ }^{7}$ - részt vehetnek egy közös játékban, cinkossá, beavatottá válhatnak.

A színház rituális jellege tehát könnyen megteremthető. Az alkotók számára ezúttal a legfőbb feladat, melyet a hit kérdésének elvontsága, filozofikussága tesz igazán nehézzé, hogy hogyan tudják a mindenkori gondolkodó ember hitre való vágyakozásának és kételkedésének harcát hitelesen, didakszis nélkül megjeleníteni. ${ }^{8}$

\section{A Jézus történet színpadi megjelenítésének nehézségei}

Számunkra a nyitottság, a kétség, a kétértelműség fenntartásának egyik legfontosabb eszköze a változó idejü-nézőpontú történetmesélés, az objektivitás állandó megkérdőjelezése volt.

Az egymásnak ellentmondó, eltérő részletek megjelenítése persze nem eredeti gondolat, hiszen már a kanonizált Szentírás is négy evangéliumot, négyféle verziót tartalmaz. Mi csupán ezt a hagyományt követtük.

Egy történet több lehetséges verziójának érzékeltetése egy művön belül a narratív műfajokban a legegyszerübb, hiszen az író könnyedén váltogathatja az időt, a nézőpontot, felülírhatja az addigi információkat. A próza mellett a film alkalmas leginkább a többszólamú, többszempontú elbeszélés megjelenítésére. Nem véletlen, hogy több regényt vagy modern filmes változatot tudunk említeni Jézus életének témájából, mint színpadi alkotást. ${ }^{9}$

A narráció középpontba állításának legfőbb veszélye, hogy elvész a drámaiság, az „itt és most” ereje; nem lesz átélhető a pillanat. Az érzékek, érzelmek helyett, túlságosan nagy hangsúlyt kap az intellektuális befektetés, az önrefle-

7 Egy ilyen sajátos eltérés az „eredetitől”: a három királyok időbeli megjelenésének szétválasztása, mely egy igen prózai körülményből, a társulat létszámából adódott. A harmadik jelenetben megismerünk két japán üzletasszonyt, akik elmondják, hogy harmadik társuk „rosszul lett a bangkoki repülőtéren és kórházba kellett szállítani”; pár perccel később, egy döntő pillanatban megjelenik az említett harmadik japán nő, aki „hál isten, jobban lett, és talált egy gyors csatlakozást”. Ebben a pillanatban az első két japán nőt játszó színész már Máté Edinaként és Máté Marikaként van a színpadon. A nézők mindig különös lelkesedéssel reagálnak erre a „privát-történetre”.

8 A feladat nehézségét, komolyságát mutatja, hogy alig születik kortárs drámai mű Jézus személyéről, életéről. Annál gyakrabban ismerhetjük fel a „megváltó”, a „messiás" figuráját korabeli-modern környezetben, konkrét történelmi személy alakjában, vagy fiktív figuraként.

9 És a botrányos, polgárpukkasztó művek és a minden karácsonykor levetített kommersz, képeskönyv-szerü filmek mellett olyan jelentős múvészi alkotások is születtek, mint például Pasolinitől a Máté evangéliuma. 
xió. Ezt szem előtt tartva, a drámai és narratív elemek ideális egyensúlyának megteremtése volt a célunk, melynek megteremtésére két alapvető eszközt használtunk fel a zenét és a humort.

Bizonyos epizódokról kórusok vagy áriák tudósítanak. A Darvas Ferenc által komponált zene, mely elsősorban Mozart Requiem és Pergolesi Stabat Mater címú szakrális múveire épül, amellett, hogy ismertségével a történethez hasonlóan, a nézőkkel közös tudásra, élményanyagra apellál, kontrasztot állít a darab profán jelenidejüségének, ugyanakkor kikerülhetetlen érzéki, érzelmi hatást gyakorol.

A zene szervülését szolgálja, hogy az orvost játszó színész zongorázik és a nézők feje fölött egy-egy emelvényen a nagybőgős és a csellista kórházi ápolónak öltözve játszik. Az utolsó előtti, bolondokházában játszódó jelenetben egyébként meg is szólalnak az ápolók, és miután hangszereiket otthagyva távoznak, felhangzik felvételről az eredeti Pergolesi mű első tétele, a „megfeszítés" kísérőzenéjeként. (Ez az egyetlen gépi zene az előadásban.)

A narráció humorforrásként való felhasználása már az első mondatokban is megjelenik. Az előadás kezdetén Béla atya felolvassa $A$ Szürke Galamb Evangéliuma címü könyv első mondatait. Meghitt, a szavak lefestő erejét múködtető hangon kezdi a mesét, majd a színpadon épp jelenlevő szereplőket (köztük önmagát) mutatja be ironikus felhanggal:

Béla atya: „Október hó első napján, pontban délelőtt tízkor, Máté Edina a Szegedi Hittudományi Egyetem másod évben elbocsátott hallgatója, kilépett az Országos Pszichiátriai és Neurológiai Intézet főbejáratán, melyet a köznyelv egyszerűen csak Lipótnak nevezett. A portásfülke mellett elhaladva azonban, nem a piros-fehérre festett elektromos sorompó felé fordította lépteit, hanem jobbra, a park hársainak irányába, mintha csak a Pesthidegkút felől érkező széllökésnek engedelmeskedett volna. A szél olajon pirított hagyma illatát sodorta magával. "Már nekiláttak az ebédnek az alagsori szakácsok!" - gondolta a meggyötört arcú, fiatal lány, majd a hársak közt köralakban elhelyezett padok egyikén megpillantotta a három férfit, mely három férfi közül kettő oly igen ismerős volt számára. (Egyikük, a görbe hátú Béla atya, egy könyvből olvasott fel éppen középmagas, kellemesnek hitt hangján.) Edina nagybátyja, az erősen kopaszodó Máté József, ki hiúságból rendszeresen tarra borotválta fejét, feszülten figyelte az ismeretlen harmadik arcát, ki bíborszínű inget viselt hófehér köpenye alatt." 
A jelen és múlt egyidejűsítésére, a narráció önreflexivitásának humoros kiaknázására a legpregnánsabb példa a darab egy későbbi pontján Béla atya és az orvos összecsapásában hangzik el:

Béla atya (olvasva): „Ekkor Béla atya - akit a tanítványok váratlan megjelenése már kellően felbőszített - kimondott egy olyan mondatot, amit önmaga sem értett egészen pontosan: („fejből" - jelenidőben) „Na most, doktor úr, én szeretnék eloszlatni önben egy téveszmét! Attól még, hogy valaki katolikus, még nem jelenti automatikusan azt, hogy hülye is!"

Az előadás humora egyébként visszafogottabb, intellektuálisabb a korábbiaknál. Másfél óra alatt csupán egyetlen káromkodást hallunk. ${ }^{10} \mathrm{~A}$ trágárság ökonomikus használata az eddigi előadásokban is cél volt, de ha a helyzet hitelessége vagy épp az ellenpontozás megkövetelte, gyakran előfordultak káromkodások. Ez az első előadás, melyben a szerző tudatosan kerülte a csúnya szavak használatát.

\section{Jézus mint színpadi alak}

Az önmagában hiteles és izgalmas, nyitott történetmesélés, az elképzelt nézői tudásnak megfelelő információadagolás mellett a mi esetünkben a legnagyobb írói-rendezői-színészi feladatot Jézus figurájának megformálása jelentette.

A középkori misztériumjátékok előadói és nézői számára mérvadó forrást jelentett a keresztény képzőművészet. A színpadi figura nem sokban térhetett el a templomi ábrázolásoktól.

10 Az egyetlen káromkodás Béla atya szájából hangzik el, amikor megpróbálja magához téríteni Edinát, hogy cáfolja meg az ellene szóló vádakat:

„Béla Szólalj meg! Nem hallottad mit mondott az orvos? Közveszélyes őrültek közé fognak zárni! Ezt én soha sem akartam! Én csak azt akartam, hogy gyógyulj meg! Edina! Mondd meg az orvosnak, hogy te soha sem tettél olyan szörnyúségeket! Emlékszel? Nem szóltam egy szót sem mikor azt hazudtad, hogy én szerelmes vagyok beléd, pedig papot nem lehetett volna jobban megalázni! Cserébe én nem kérek mást, csak azt, hogy menj oda az orvoshoz, és mondd meg neki, hogy ez a két nő hazudik.

Edina Bocsánat, nem hallom.

Béla Te hülye! Pofon. Te idióta! Pofon. Sír. A kurva anyádat! A kurva anyádat! El."

A hiány legfrappánsabb példája a titkárnő, Angyal Hajnal éneke, aki dal közben egy hatalmas puskával fenyegeti a szerelmének csalódást okozó két japán üzletasszonyt:

"Karácsonyi áhítatból

Kitéptétek Hajdú Lászlót

Idehívtátok hiába

Túnjetek el a..." 
A mai megformálónak sokkal nagyobb a szabadsága (esetleg inspirálóan hathat az idők során változó képi megjelenés, ${ }^{11}$ vagy a kánon változása: Jézus életének mely jelenete került előtérbe a különböző korokban), de az elsődleges forrás ma is a Biblia, a négy evangélium.

A figyelmes olvasás során egyik legmeghatározóbb benyomásunk az volt, hogy a Szentírásból kirajzolódó kép mennyire ellentmondásos viszonyban áll az általánosan elfogadott Jézus sztereotípiával, mely a szeretetet, a türelmet hangsúlyozza (ehhez a végtelen bölcsesség mellett, gyakran valami egyhangú szelídség és passzivitás is társul); a konkrét történetekben ugyanakkor megjelenik a düh, a szenvedélyes, harcos indulat, sőt akár az értetlenséggel szembeni türelmetlen arrogancia is.

Szándékunk az volt, hogy a színpadi figura valamilyen módon tükrözze ezeket az ellentmondásokat, hiszen egy dinamikus, változó személyiség sokkal inkább alkalmas egy dráma központi alakjának, mint egy egysíkú, sematikus, passzív figura.

Jézus kifürkészhetetlen, gyötrődő, olykor gyarló emberi voltának plasztikus megformálásánál már csak lényének isteni dimenziója, sugárzó különlegessége nehezebb feladat. A többi emberre gyakorolt, semmihez sem hasonlítható hatást "színpadi környezetének" kell megoldania. A megvalósításnál fontos szerepet kaptak a színpadon véghezvitt "csodák”: a víz borrá változtatása, az égbe emelkedés stb.

Jézus istenségét, kiemelkedőségét cselekedetei és környezetének hite mellett, a Bibliát olvasva, leginkább szavainak erejében érezzük. Különös, enigmatikus nyelvezete, mely gyakran az érthetőség-érzékiség határán mozog, a hit nélküli, távolságtartó racionalitással közeledő befogadót is magával ragadja. Mivel a mi előadásunkban Jézust mai környezetbe helyeztük, ezt az archaikusnak is nevezhető, képekben gazdag, költői nyelvezetet nem használhattuk. A művészi kifejezés eme fontos pillérétől megfosztva, a mában elfogadható, mégis különleges, átlagfeletti személyiség megjelenítésének kidolgozására került a hangsúly.

Mivel nehéz lenne elképzelni, hogy ma bárkit is börtönbe zárnának azért, mert Isten gyermekének képzeli magát, a Jézus és a hatalom közötti alapkonfliktust, a magát megváltónak képzelő lány és az elmeorvos közötti viszonyban helyeztük el. ${ }^{12}$

11 „Az 5. sz.-tól a középkor végéig a keresztes dicsfény jelöli ki Jézust [...], az ókeresztény múvészetben többnyire valamilyen szimbólummal helyettesítik (kereszt, bárány, koszorú, Krisztus-monogram) [...]. Krisztus maga vagy kortalanul fiatalon, vagy méltóságát jelző szakállal jelenik meg az ókori filozófusképek mintájára mint mennyei tanító. [...] A keresztrefeszített szenvedő Krisztus csak a középkorban válik a keresztény múvészet témájává. [...] A gótikától kezdve hangsúlyozzák Krisztus alakjának szépségét is. [...] A reneszánsz múvészek [...] a tökéletes antik szépségideálnak megfelelően ábrázolják Krisztust. Emellett korábban ismeretlen realizmussal is ábrázolják, mint valóságos embert. (Caravaggio, Rembrandt)" A keresztény müvészet lexikona, szerk. Jutta Seibert, ford. Harmathné SzILÁGyı Anikó (Budapest: Corvina Kiadó, 2004), 144-151.

12 A hatalom és az uralkodó egyház figurája a mi történetünkben is különválik, a világi 
Jézust tehát nem börtönbe zárják, hanem elmegyógyintézetbe. Ez elképzelhetőbb a mai társadalom hiteles reakciójaként. Az elmeorvos-páciens viszonyból már adódott az irány, a lehetőség, hogy merre mozdítsuk el az eleinte sztereotipikusnak, erőtlennek, élettelennek ható (lány)messiás figuráját. A „hitetlen” külvilág bélyegét: az „őrültség”-et használtuk fel.

Az őrült, a bolond mint szereplő, mint szerepkör egyébként szintén eléggé problematikus a drámairodalomban. Leginkább rezonőrként alkalmazzák, kívülállóként vagy a történet szereplői és a nézők közötti összekötőként. (Lásd Shakespeare bolondjait.)

Egy központi figuránál viszont fontos a változás lehetősége. Az őrült attól lehet érdekes igazán, hogy nem tudjuk, valóban őrült-e vagy csak tetteti, vagy egyszerúen valami másik dimenzióban mozog, ami a többiek számára érthetetlen, de a nézők idővel megfejthetik. Abban a pillanatban, hogy egy figuráról kiderül, hogy bolond, vagyis nem ura gondolatainak, tetteinek, döntéseinek, érdektelenné válik a néző számára; pusztán orvosi, klinikai esetként tekintünk rá.

Ugyanakkor őrültet játszani (amellett, hogy nagyon komoly kihívás), mégis igen teátrális, hálás színészi feladat, mivel nagyon szélsőséges állapotokat lehet megjeleníteni, éles váltásokkal lehet állandóan kiszámíthatatlanná, szuggesztívvé tenni az alakítást.

Jézus figurájának kétféle: külső és belső megjelenítése lett a kulcsa az előadásunknak. Belső alatt értem azt az átéltséget, hitelességet, megszállottságot, amit a tanítványok és a hívők felé közvetít, külső alatt pedig a figyelemfelkeltő őrültséget, mely a hitetlenül, távolságból szemlélődők számára megjelenik. A döntés tehát, hogy Máté Edina, a lánymessiás Isten lányának vagy egy zavart elméjü fiatal lánynak tekinthető-e, a nézőre van bízva. A kétféle kép feszültsége, összjátéka szolgál az előadás egyik alappilléréül. ${ }^{13}$

hatalmat az orvos, a kanonikus egyházat a katolikus pap képviseli. Heródes figurája is megjelenik a rettegett vidéki polgármester alakjában, aki a későbbiekben a bulgakovi Lévi Mátét is magába foglalva, átalakul Péterré, az egyik legfontosabb tanítvány szerepét tölti be.

13 A Máté Edinát alakító törékeny, már-már áttetsző alkatú, kortalannak látszó színésznő (Roszik Hella) játéka a tiszta és elborult pillanatok éles váltásaival, állandósult, kényszeres, ugyanakkor tétova öngyújtó és cigarettakereső-mozdulataival, az előadás egyik legerősebb, legemlékezetesebb pontja. Vö. „Roszik Hella igen szuggesztíven formálja meg a Lipótmezőre beutalt lányt, lógó intézményi hálóingben, avval a jellegzetes járással, amivel kórházi folyosókon szoktak sompolyogni a nőbetegek, ráérősen és nyughatatlanul. Keze állandóan gyufa vagy öngyújtó után matat, hogy még slukkolhasson néhányat, mielőtt visszavonul a neki kijelölt ágyhelyre. Roszik Edinája egyszerű is, rafinált is - zsótérosan tiszta és sugárzó az arca. Mindenesetre megvan benne a képesség az állóvíz felkavarására." StuBER Andea, „Isteni szórakozás: Pintér Béla: Az őrült, az orvos, a tanítványok és ördög", Színház 40, 12. sz. (2007): 17-19, 17, 18. 


\section{Kálvária - halál a színpadon}

A Krisztus figura hiteles megidézése és a többidejű-, nézőpontú történetmesélés mellett a legnagyobb problémát az utolsó epizód, a keresztrefeszítés és feltámadás mozzanatainak színrevitele jelentette. Edina megjósolja, hogy „[...] a betegek kijátsszák az ápolók éberségét, és egy este megerőszakolnak, aztán felakasztanak a sporttelep kosárlabdaállványára." Az erőszaktétel a figura neméből adódik, hiszen ez a legnagyobb, legtipikusabb megaláztatás, ami egy nővel történhet, az akasztás pedig a gyilkosság és az égbeemelkedés megfelelőjeként működik. A jóslatnak tehát be kell teljesülnie.

Halál és szexuális aktus a színház két legnagyobb tabuja a mai napig. Igaz, már rég nem szent titkokról, erkölcsi tabukról van szó, sokkal inkább a formai, múvészi megjelenítés problémájáról: mi az, amit még el lehet hinni, hogyan lehetséges a leghatásosabb illúziót kelteni, a néző fantáziáját működtetni, cinizmusát, színházi néző-tudatát elaltatni. ${ }^{14}$

Ennek a jelenetnek a megoldása, kivitelezése a három eddig felsorolt kardinális probléma közül a legkonkrétabb, legszűkebb, mégis nagy horderejü, hiszen az utolsó előtti jelenet, sokak számára itt dől el végképp, hogy az előadás híveivé válnak, vagy sem.

A bolondokházában játszódó epizód teljes sötétségben indul. Furcsa, meditatív zenét hallunk: kitartott hangok a bőgőn és a csellón, majd egy erősen szuggeráló férfihang mond valami versfélét, mely akár az egész darab üzenete is lehetne:

„Mindaz, aki jajgató asszonytól született e földre, Tudja, hogy élt valaha egy férfi, kit az Ember Fiának neveztek.

De a vágy a hitre - mely oly parancsoló szüksége a léleknek, mint a testnek az éhség-

A vágy a hitre bizonytalan, s elhatalmasodik bennünk a velünk született kétség.

Mert mi van, ha létezett ugyan, de ember volt csupán.

És tetteit a kései tanítványok színezték Isteni tetté.

S az ígért Mennyország - hol az igaz lélek tovább él, mikor a test már a sírban hever,

Az ígért mennyország nem létezik, csak a törvény, hogy:

Porból vagy és porrá leszel!"

14 A realista, naturalista megoldás csak olyan extrém esetekben fordult elő a színháztörténetben, mint például a római színházban, amikor valóban megölték a rabszolgákat, vagy a hatvanas évek performanszaiban, melyekben a megvalósuló szexuális aktus (akár a néző részvételével) része volt a színházi rítusnak. 
Két másik ápolt megszólalása után meggyulladnak a gyertyák bevilágítva a kis forgószínpadot, melyen négyen ülik körbe az ötödik, középen álló alakot. Mindannyiukon egyforma fehér kórházi hálóing, hosszú paróka, szakáll, bajusz (vallásos zsidó férfi attribútumok).

A betegtársak arra kérik Edinát (természetesen ő a középen álló figura) hogy idézzen egy részletet a Bibliából, az eredeti városneveket megváltoztatva - magyar és erdélyi nevekkel helyettesítve. Edina vonakodva bár, de teljesíti kérésüket, mely társait egyre lelkesebbé teszi. Az ápolók hiába invitálják őket a tévészobába, a betegek most még az „összefoglaló” kedvéért sem hagynák félbe játékukat. Amint egyedül maradnak, egy újabb idézetet kérnek Edinától, mely Krisztus testéről és véréről szól.15

Közben az egyik beteg bekapcsol egy magnót; ketten meztelenre vetkőznek, majd lassú koreografikus mozdulatokkal beöltöznek római katonának. Jelmezeik: kezdetleges papírszoknya, csákó, kezükben papírkard (amelyeket elképzelhetően valamelyik rehabilitációs foglalkozáson vagy munkaterápián készíthettek maguknak), és a zenét követő, hol meglóduló, hol lelassuló, félig múvészien táncos, félig suta, esetleges mozdulatokkal, egymás után rontanak rá a fekvő Edinára, és a szexuális aktus mozdulatait ismétlik. A "soronlévőt" társa ütemes mozdulatokkal ütlegeli papírkardjával. Aki „elvégezte feladatát”, félig összeomolva, rogyadozó lábakkal, zokogva adja át helyét.

Közben a két másik ápolt közül az egyik fáziskéséssel, női sikoltás, zokogás hangjaival, mikrofonnal kíséri a mozdulatokat, a másik trombitaszóval harsogja túl a zenét. Az első két ápolt végül megkoronázza és felakasztja Edinát. A lány teste eltűnik a szemünk elől. Egy jelenettel később Edina egyik égből lezuhanó, elnyűtt műanyagpapucsa zárja le ezt az epizódot és az előadást is.

A hatáskeltés eszközeként elsősorban a zenét kell kiemelni, mely szakralitásával, fenségességével ellenpontozza az erőszakos cselekedetet. A rituális mozdulatsorok, a beöltözés, a nyilvánvalóan mesterségesen elkülönített fizikai és vokális jelenlét, a történések felmutatásának, teatralitásának hangsúlyozása az átélhetőséget szolgálja. Mindenképp kerülni akartuk a reális, naturális színházi eszközöket, valamint a jót és rosszakat - áldozatot és gyilkosokat didaktikusan elkülönítő megjelenítést.

15 „Bizony, bizony mondom néktek: ha nem eszitek az Emberfia testét, és nem isszátok a vérét, nincsen élet tibennetek. Aki eszi az én testemet, és issza az én véremet, annak örök élete van, és én feltámasztom azt az utolsó napon. Mert az én testem igazi étel, és az én vérem igazi ital. Aki eszi az én testemet, és issza az én véremet, az énbennem lakik, és én őbenne. Ahogyan engem az élő Atya küldött el, és én az Atya által élek, úgy az is, aki engem eszik, élni fog énáltalam." (János 6, 53-58.) 


\section{Elidegenített szegény színház}

\section{A kialakult formanyelv - értékelés}

Az eddigi produkciókkal szemben az a legszembeötlőbb, mennyire sokféle, egymástól radikálisan eltérő stílusú jelenet követi egymást egy előadáson belül. Korábbi előadásokban is megjelentek különböző stíluselemek egymás mellett, mégis elmondhatjuk, hogy például a Népi Rablét valamiféle rituális mozgásszínháznak tekinthető, A Sehova Kapuja és A Sütemények Királynője akár egy hagyományos prózai előadásnak is beillene, a Parasztopera és a Gyévuska pedig az operaforma újraértelmezésére tesz kísérletet.

Ebben az előadásban a különböző elemek - mozgás, ének (kórusok, áriák), beszéd (a lehető legtermészetesebb, eszköztelen színjátszás), a puritán, egyszerűségében szuggesztív látvány -, és a mindig elengedhetetlen, egyszerre kizökkentő és magávalragadó humor olyan egységet alkotnak, melyet kiforrott "Pintér Béla-stílus"-nak nevezhetünk.

A felütés szegényszínházat idéző eszköztelenség: Béla atya a nézőtéri fényben, mely lassan, fokozatosan megy le, körbe sétálva kezdi felolvasni a „könyvet": a "Szürke Galamb Evangéliumát". (A kör alakú játéktérből, melyet csupasz villanykörték világítanak meg, négy „út" fut ki sugár irányban - a nézők félkör alakban veszik körül a forgószínpadot.)

A "bevezető" felolvasás után kórus következik, melyet az összes szereplő együtt énekel - így veszi át a társulat a Béla atyát játszó író-rendezőtől a mesét, a történetmesélést, így kerülünk át a könyvből a színpad világába.

Ezután az egyik legösszetettebb jelenet következik: két japán álarcos, egyforma kosztümös nő (a „három királyok"-at idéző két japán üzletasszony) énekel és koreografikusan, egyszerre mozog, a polgármester realista stílusban, visszafogottan poentírozva prózában válaszol, a titkárnő bravúros keleti-színházi mozdulatokkal ropit oszt, és egy magyar népdal dallamára recitál.

A következő, császármetszést bemutató jelenet realisztikusan indul, majd horrorisztikus granguignolba torkollik: a hotel recepciósnője gumikesztyűben, sniccerrel császármetszést hajt végre Máté Marikán.

A Mozart Requiemének dallamára telefonáló orvos és páciens későbbi beszélgetése akár egy hagyományos prózai előadás része lehetne, majd újabb kórusok, áriák és végül a fent említett hangjátékként kezdődő, szakrális és elidegenítő elemeket egyaránt hordozó, mozgásszínházi jelenet színesíti a palettát.

A sokféleség nagy koncentrációt, erőfeszítést követel a befogadótól. A téma elvontsága mellett ez is oka annak, hogy ez az előadás nem sorolható legnagyobb közönségsikereink közé. Mégis formai szempontból egyszerre összegzésnek és előrelépésnek tartom, ami főképp a fejezet elején tárgyalt témaválasztás újfajta kihívásainak köszönhető. 